\title{
Elucidation of the active compounds and molecular mechanisms of Smilacis Chinae Rhizoma for treatment of pelvic inflammatory disease based on network pharmacology and MMGBSA-docking
}

Research

Keywords:

Posted Date: January 5th, 2021

DOl: https://doi.org/10.21203/rs.3.rs-20932/v2

License: (1) This work is licensed under a Creative Commons Attribution 4.0 International License. Read Full License 


\section{Abstract}

The authors have requested that this preprint be withdrawn due to erroneous posting.

\section{Full Text}

The authors have withdrawn this preprint from Research Square. 